\title{
Factors associated with the discontinuance of outpatient follow-up in neonatal units
}

\author{
Fatores associados à descontinuidade do seguimento ambulatorial de egressos de unidades neonatais
}

Factores asociados con la interrupción del seguimiento ambulatorio de recién nacidos tras el alta de unidades neonatales

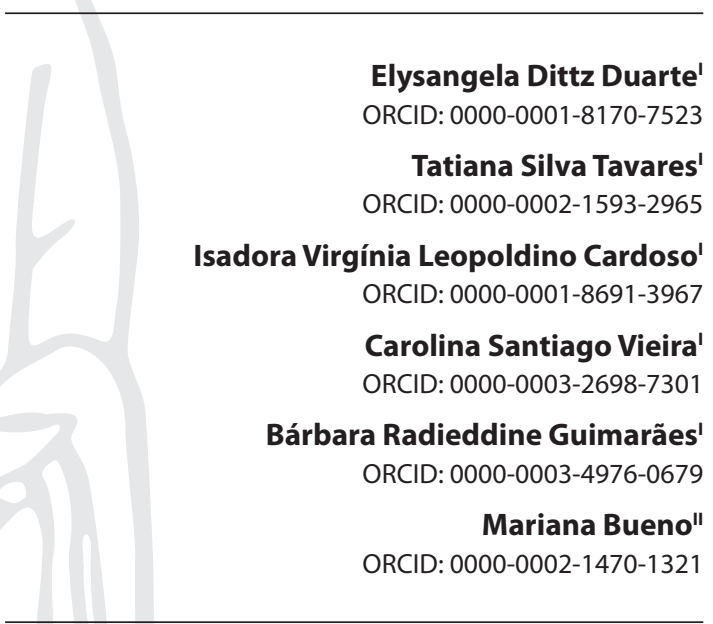

'Universidade Federal de Minas Gerais. Belo Horizonte, Minas Gerais, Brazil.

"The Hospital for Sick Children. Toronto, Ontario, Canada.

How to cite this article:

Duarte ED, Tavares TS, Cardoso IVL, Vieira CS,

Guimarães BR, Bueno M. Factors associated with the discontinuance of outpatient follow-up in neonatal units.

Rev Bras Enfem. 2020;73(3):e20180793.

doi: http://dx.doi.org/10.1590/0034-7167-2018-0793

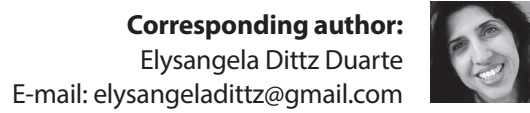

EDITOR IN CHIEF: Antonio José de Almeida Filho ASSOCIATE EDITOR: Hugo Fernandes

Submission: 10-15-2018

Approval: 04-18-2019

\begin{abstract}
Objectives: to identify predisposing and enabling factors as well as the health needs associated with the discontinuance of outpatient follow-up of newborns who were hospitalized at neonatal intensive care unit. Methods: cross-sectional study, using the behavioral model of health services use. The study was composed of 358 mothers and newborns referred to the outpatient follow-up after discharge. Characterization, perception of social support, postnatal depression, and attendance to appointments data were collected, analyzed by the R software (3.3.1). Results: outpatient follow-up was discontinued by $31.28 \%$ of children in the first year after discharge. In multiple regression analysis, the chance of discontinuance was higher for newborns who used mechanical ventilation $(\mathrm{OR}=1.68 ; 95 \% \mathrm{Cl} 1.04-2.72)$ and depended on technology (OR $=3.54 ; 95 \% \mathrm{Cl} 1.32-9.5)$. Conclusions: predisposing factors were associated with the discontinuance of follow-up; enabling factors and health needs did not present a significant association. Children with more complex health conditions require additional support to participate in follow-up programs, thus ensuring the continuity of care.
\end{abstract}

Descriptors: Continuity of Patient Care; Ambulatory Care; Intensive Care Units, Neonatal Pediatric Nursing; Needs Assessment.

\section{RESUMO}

Objetivos: identificar fatores predisponentes e capacitantes e necessidades de saúde associados à descontinuidade do seguimento ambulatorial de recém-nascidos egressos de terapia intensiva neonatal. Métodos: estudo transversal, utilizando o modelo comportamental de utilização de serviços de saúde. Participaram 358 mães e recém-nascidos encaminhados ao seguimento ambulatorial à alta hospitalar. Foram coletados dados de caracterização, percepção de apoio social, depressão pós-parto e assiduidade às consultas, sendo analisados no software $R$ (3.3.1). Resultados: o seguimento ambulatorial foi descontinuado por $31,28 \%$ das crianças no primeiro ano após a alta. Em análise de regressão múltipla, a chance da descontinuidade foi maior nos recém-nascidos que utilizaram ventilação mecânica ( $O R=1,68$; IC 95\% 1,04-2,72) e dependiam de tecnologia (OR = 3,54; IC 95\% 1,32-9,5). Conclusões: fatores predisponentes estiveram associados à descontinuidade do seguimento; fatores capacitantes e necessidades de saúde não apresentaram associação significativa. Crianças com condições de saúde mais complexas requerem suporte adicional para participação nos programas de seguimento e garantia da continuidade do cuidado.

Descritores: Continuidade da Assistência ao Paciente; Assistência Ambulatorial; Unidades de Terapia Intensiva Neonatal; Enfermagem Pediátrica; Determinação de Necessidades de Cuidados de Saúde.

\section{RESUMEN}

Objetivso: identificar los factores predisponentes y facilitadores, y las necesidades de salud asociadas a la interrupción del seguimiento ambulatorio de recién nacidos tras el alta de unidades de cuidados intensivos neonatais. Métodos: estudio transversal, que utilizó el modelo conductual de utilización de servicios de salud. Participaron 358 madres y recién nacidos, que fueron orientados al seguimiento ambulatorio para el alta hospitalaria. Se recogieron los datos de caracterización, de percepción de apoyo social, de depresión posparto y de asiduidad a las consultas, siendo analizados en el software R (3.3.1). Resultados: el siguimiento ambulatorio fue interrumpido por el $31,28 \%$ de los niños durante el primer año tras el alta. En el análisis de regresión múltiple, la probabilidad de interrumpir el seguimiento fue mayor entre los recién nacidos que utilizaron ventilación mecánica $(O R=1,68$; IC 95\% 1,04-2,72) y dependían de la tecnología (OR = 3,54; IC 95\% 1,32-9,5). Conclusión: los factores predisponentes fueron asociados con la interrupción del seguimiento; sin embargo, los factores facilitadores y las necesidades de salud no presentaron una asociación significativa. Los niños que presentaban condiciones de salud más complejas requirieron apoyo adicional para participar en los programas de seguimiento y garantizar la continuidad del cuidado.

Descriptores: Continuidad de la Atención al Paciente; Atención Ambulatoria; Unidades de Cuidado Intensivo Neonatal; Enfermería Pediátrica; Evaluación de Necesidades. 


\section{INTRODUCTION}

Over the past few decades, it is possible to observe an increase in the survival of newborns born with perinatal diseases or congenital malformations, with compromised health resulting from the condition at birth and care received in neonatal intensive care units (NICU) ${ }^{(1-3)}$. Investments have been made in different areas to improve the health of these children to ensure good care during hospitalization and after discharge. In Brazil, in 2015, the Política Nacional de Atenção Integral à Saúde da Criança [National Policy of Integral Health Care for Children] was established, having as strategies humanized attention to premature and low-weight newborns by the "Kangaroo Method" and the follow-up of newborns at risk after discharge, actions shared between the specialized and basic care ${ }^{(4)}$.

Concerning outpatient follow-up, studies have verified its contribution to the timely diagnosis of changes in growth and development, referral to specialized care, morbidity and mortality reduction of newborns and support to parents regarding the children's care ${ }^{(5-6)}$. Additionally, the recording of information on the follow-up has allowed the knowledge concerning the results of care to children who were hospitalized at a NICU(6).

However, international studies that investigated non-adherence to outpatient follow-up point out that discontinuity rates range from $20 \%$ to $46 \%{ }^{(7-8)}$ in the second appointment, reaching $18.8 \%$ in the first two years ${ }^{(9)}$. Among related factors, we can highlight: distance between residence and service, preference for a specific health professional, illness in the family, change of address, unfavorable socioeconomic and cultural characteristics of families, and having other children ${ }^{(7-10)}$. A Brazilian study, conducted in the state of Minas Gerais, showed that $19.8 \%$ of children who were hospitalized at a NICU with referral to the outpatient follow-up did not attend any appointment in the first 12 months of life ${ }^{(11)}$. Aspects of the discontinuity of outpatient follow-up of children at risk have been little explored in the national context, especially the factors that can contribute to its occurrence.

It is known that children at risk who were hospitalized in NICU present the highest risk of changes in growth and development as well as of occurrence of morbidities in the medium and longterm. This risk is aggravated when these children do not get a qualified assistance that encompass the peculiarities of their needs $s^{(2,11)}$. We considered, therefore, the need to understand the factors associated with the discontinuance of outpatient follow-up and the possible interferences in the families' decision regarding the use of health care services to children who were hospitalized at a NICU.

It is known that the family is often responsible for determining the use of health services by its members, especially children ${ }^{(11)}$. To understand and explain how the choices are made by individuals regarding the use of health services, different theoretical references have been used, for example the behavioral model proposed by Andersen ${ }^{(12)}$. This model aims to explain how predisposing, enabling, and health need-related factors influence the use of the services ${ }^{(12)}$.

According to this model, the predisposing factors refer to individual characteristics prior to the illness situation, being subdivided into three categories: demographic variables of the individuals who compose the family group; social structure, traditionally evaluated by the variables occupation, ethnicity, and education; and beliefs, the values assigned to the disease. Enabling or facilitating factors refer to the possibility of access to health services, including income, proximity between the residence and the health service, access, and number of services offered. As for the factors related to health needs, they refer to the health condition self-perceived by the user, regardless of the health professional's assessment ${ }^{(12)}$.

This study's hypothesis is that predisposing and enabling factors as well as the health needs of the mothers and of the newborns may be associated with the discontinuance of outpatient follow-up.

\section{OBJECTIVES}

To identify predisposing, enabling, and health need-related factors associated with the discontinuance of outpatient followup of newborns who were hospitalized at a NICU.

\section{METHODS}

\section{Ethical aspects}

The research was developed considering Resolution no. $466 / 2012$ of the National Council of Health/Ministry of Health, approved by the Research Ethics Committee of the hospital where the data were collected.

\section{Study design, location, and period}

This is a cross-sectional study performed at a Neonatal Intensive Care Unit and at the outpatient follow-up service of a philanthropic hospital in the state of Minas Gerais, Brazil. In the year of this study, 952 newborns were admitted to the NICU, with an average of 79 newborns per month.

To care for newborns in the neonatal unit and outpatient service, the hospital has a specialized multidisciplinary team comprising nurses, physiotherapists, occupational therapists, speech therapists, neurologists, pediatricians, psychologists, and social workers. Children referred to the follow-up are accompanied by at least one specialty, according to their need, until two years of corrected age, in an average of 250 to 300 appointments per month. If any changes in development are identified, the children are referred to intervention services, which does not interrupt the outpatient follow-up.

\section{Population, sample, inclusion and exclusion criteria}

All 358 children and their mothers who were discharged from the NICU from October 1, 2014, to September 30, 2015, which were referred to the service by professionals of one or more specialties in the institution's outpatient service were included. We excluded from the study children whose discharge records did not report the referencing to the institution's outpatient specialties. 


\section{Study protocol}

The behavioral model of health services use ${ }^{(12)}$ guided this study's development and the selection of variables that influenced the use of health services for the preparation of the data collection instrument. The instrument has undergone pilot testing, and no necessary changes were found. The outcome under study was the "discontinuity of outpatient follow-up". We considered as discontinuity the non-attendance of the child to two or more consecutive outpatient appointments in this service, or non-attendance in a period of over six months to all specialties to which the child was referred to in the outpatient service studied.

Variables related to predisposing factors were: sex; gestational age at birth ( $<37$ weeks or $\geq 37$ weeks); weight at birth in grams ( $<$ 2500 or $\geq 2500$ ); diagnostic at the time of admittance to the NICU; mechanical ventilation during the hospitalization period (yes or no); technology dependence at the time of discharge (yes or no). The following maternal variables were also used: age ( $<18$ years, between 18 and 29 years, $\geq 30$ years); previous children (yes or no); educational level (illiterate/some elementary school, elementary school/some high school, high school/some higher education, and $3^{\circ}$ higher education); declared ethnicity (white, black, mixed, or others); marital status (with partner or without partner); smoker (yes or no); use of drugs (yes or no); Edinburgh postnatal depression scale (EPDS), and the social support scale (Medical Outcomes Study - MOS), which were translated and adapted to the Brazilian culture and have been frequently used in national studies ${ }^{(13-15)}$.

The Edinburgh scale is composed of ten items that assess common puerperium depressive symptoms, with a score ranging from 0 to 30 points ${ }^{(16)}$. For this study, we considered that a score of 12 or more points indicated the presence of depressive symptoms. The social support scale assesses an individual's perception regarding the degree of social support, including the material, affective, and emotional dimensions, as well as information and positive social interaction in 19 items. Each item presents five answer options, ranging from 1 to 5, in the following order: "Never", "rarely", "sometimes", "often", and "always". The final score ranges from 19 to 95 points, the higher the final score, the greater the perceived social support ${ }^{(17)}$.

For the facilitating or enabling factors, the following variables were used: social class $(A / B, C, D / E)^{(18)}$; mothers' report regarding the existence or lack of guidance received from the professionals, concerning follow-up after discharge; receiving the continuous provision benefit (yes or no) - which, according to the Organic Law of Social Support ${ }^{(19)}$, is an assistance benefit that guarantees one minimum monthly wage to people with disabilities, considered incapable of fully and effectively participating in society -; receiving other type of benefit (yes or no); referred difficulty to go to the outpatient service (yes or no); means of transport used to go to the outpatient service (own car, bus, or vehicle provided by the city hall); distance between the residence and the outpatient service $(<100 \mathrm{~km}, \geq 100 \mathrm{~km}$ and $<200 \mathrm{~km}, \geq 200 \mathrm{~km})$; and city of origin (Belo Horizonte or cities from the rural area of the state of Minas Gerais).

The need in health was evaluated through questions asked to the mothers regarding their understanding about the health condition of their children and the need for care and outpatient follow-up. To this end, we used a Likert-type questionnaire with answer options ranging from "very high" to "very low" or "very good" to "very poor". Once prepared, the instrument was sent to four professionals (physician, nurse, physiotherapist, and occupational therapist) who acted in the follow-up of children of risk to verify the relevance of its content considering the investigation's goals. No modifications were suggested for the instrument.

The components of Andersen's model ${ }^{(12)}$ and the variables selected for the study are presented in Figure 1.

Data were collected on three occasions: initially, we assessed the eligibility of the newborns at the time of discharge from the NICU, from data collected in the medical records and discharge report concerning birth, hospitalization, and outpatient appointments scheduled. At the time of attendance to the first appointment at the outpatient follow-up, data were collected with the mothers, through the application of the data collection instrument and the scales previously mentioned. Finally, we verified the attendance of these children to the outpatient appointments from October 1, 2014, to October 31, 2016. Attendance, absence, or rescheduling of the appointments were checked daily, for 12 months after inclusion of each child, and recorded in the instrument for verification of attendance to the appointments. The data were collected using the Medomai Knackhq platform using a mobile device with internet connection, which allowed real-time collection and storage.

\section{Analysis of the results and statistics}

To evaluate the influence of predisposing, enabling, and health need-related factors on the outcome (discontinuity), we 
initially carried out a univariate analysis by logistic regression analysis. From the univariate analysis, a pre-selection was made of potential predictors for the occurrence of discontinuity, being included in the model variables with $p$-value $<0.25$. The selected variables were then adjusted to multivariate logistic regression models and, in these models, the Backward method was applied for final selection of the variables. For the Backward method, a $5 \%$ significance level was adopted. To assess the quality of the logistic regression adjustment, the Hosmer-Lemeshow test ${ }^{(20)}$ and Nagelkerke's pseudo R2 ${ }^{(21)}$ were used. The analysis was performed using the $\mathrm{R}$ software (version 3.3.1).

\section{RESULTS}

During the study period, 358 children initiated outpatient follow-up for care of children at risk. Of these, 246 (68.72\%) attended the follow-up during the first year after hospital discharge and $112(31.28 \%)$ discontinued the treatment. Regarding the time of discontinuity to the follow-up, $25 \%$ of children discontinued in the first six months and the remainder up to 12 months after discharge. The characterization data of children indicated: corrected gestational age, average of 35.6 weeks $( \pm 4.35)$, mean Apgar score in the first minute $7.1( \pm 2.30)$ and in the fifth minute 8.7 ( \pm 1.48), with 29 children (8.87\%) presenting an Apgar score of less than 7 in the fifth minute of life. The most prevalent diagnoses at the time of hospitalization were: jaundice (85.99\%), pulmonary disorders (60.61\%), and cardiological disorders (25.42\%).

As for the mothers, the average age was 27 to 37 years ( \pm 7.16$)$, natural childbirth prevailed (53.73\%), and the average monthly family income was of $\mathrm{R} \$ 1,962.36( \pm 2,815.52)$. Concerning postnatal depression, 82 mothers (23.91\%) presented depressive symptoms, which corresponds to the presence of the score $>12$. The average score of the social support scale was 85 , indicating a high perception of social support by mothers.

Table 1 presents the data on the predisposing factors of discontinuity to outpatient follow-up of children who were hospitalized at the NICU. Mechanical ventilation $(p=0.027)$ and technology dependence at the time of hospital discharge $(p=0.008)$ showed a significant association to the discontinuity of the follow-up.

The data presented in Table 2 refer to the enabling factors for the discontinuity of outpatient follow-up of the children who were hospitalized at the NICU. Only the referencing to follow-up after discharge was shown to be significantly associated to the discontinuity of outpatient follow-up.

Table 1 - Predisposing factors to the discontinuity of outpatient follow-up of children who were hospitalized at the neonatal intensive care unit, Belo Horizonte, Minas Gerais, Brazil, 2016

\begin{tabular}{|c|c|c|c|c|c|}
\hline \multirow[b]{2}{*}{ Variables } & & \multicolumn{2}{|c|}{ Discontinued } & \multirow[b]{2}{*}{ Odds Ratio } & \multirow[b]{2}{*}{$p$ value } \\
\hline & & $\mathbf{n}^{*}$ & $\%$ & & \\
\hline \multirow[t]{2}{*}{ Sex of the child ${ }^{\ddagger \ddagger}$} & Female & 44 & 26.3 & 1.00 & - \\
\hline & Male & 61 & 35.5 & 1.54 & 0.070 \\
\hline \multirow[t]{2}{*}{ Gestational age at birth } & $<37$ weeks & 86 & 31.0 & 1.00 & - \\
\hline & $\geq 37$ weeks & 20 & 32.8 & 1.08 & 0.791 \\
\hline \multirow[t]{2}{*}{ Weight at birth } & $<2500 \mathrm{~g}$ & 92 & 32.6 & 1.00 & - \\
\hline & $\geq 2500 \mathrm{~g}$ & 14 & 25.0 & 0.69 & 0.263 \\
\hline \multirow[t]{2}{*}{ Mechanical ventilation } & No & 45 & 26.5 & 1.00 & - \\
\hline & Yes & 56 & 38.1 & 1.71 & 0.027 \\
\hline \multirow{2}{*}{ Technology dependence ${ }^{\ddagger}$} & No & 101 & 29.7 & 1.00 & - \\
\hline & Yes & 11 & 61.1 & 3.72 & 0.008 \\
\hline \multirow[t]{3}{*}{ Age Legal guardian ${ }^{\S \ddagger}$} & $<18$ years & 9 & 42.9 & 1.00 & - \\
\hline & Aged from 18 to 30 years & 57 & 29.1 & 0.55 & 0.197 \\
\hline & $\geq 30$ years & 42 & 31.6 & 0.62 & 0.311 \\
\hline \multirow[t]{2}{*}{ Previous children $\$$} & No & 56 & 29.5 & 1.00 & - \\
\hline & Yes & 52 & 32.7 & 1.16 & 0.516 \\
\hline \multirow[t]{4}{*}{ Mother's educational level ${ }^{\S \ddagger}$} & Illiterate/Some elementary school & 12 & 38.7 & 1.00 & - \\
\hline & Elementary school/Some high school & 38 & 31.1 & 0.72 & 0.424 \\
\hline & High school/Some higher education & 55 & 30.9 & 0.71 & 0.391 \\
\hline & Higher education & 5 & 22.7 & 0.47 & 0.224 \\
\hline \multirow[t]{4}{*}{ Declared ethnicity $\$$} & White & 19 & 28.8 & 1.00 & - \\
\hline & Black & 22 & 29.3 & 1.03 & 0.943 \\
\hline & Mixed & 68 & 32.5 & 0.82 & 0.568 \\
\hline & Other & 1 & 25.0 & 1.19 & 0.871 \\
\hline \multirow[t]{2}{*}{ Marital status ${ }^{\S}$} & Without partner & 37 & 30.6 & 1.00 & - \\
\hline & With partner & 73 & 31.5 & 1.04 & 0.864 \\
\hline \multirow[t]{2}{*}{ Smoker } & No & 99 & 30.6 & 1.00 & - \\
\hline & Yes & 10 & 32.3 & 1.08 & 0.844 \\
\hline \multirow[t]{2}{*}{ Use of drugs ${ }^{\S}$} & No & 107 & 31.1 & 1.00 & - \\
\hline & Yes & 1 & 20.0 & 0.55 & 0.599 \\
\hline \multirow[t]{2}{*}{ Edinburgh Scale } & $<12$ & 79 & 30.3 & 1.00 & - \\
\hline & $\geq 12$ & 27 & 32.9 & 1.13 & 0.650 \\
\hline
\end{tabular}


Table 2 - Enabling factors to the discontinuity of outpatient follow-up of children who were hospitalized at the neonatal intensive care unit, Belo Horizonte, Minas Gerais, Brazil, 2016

\begin{tabular}{|c|c|c|c|c|c|}
\hline \multirow{2}{*}{ Variables } & & \multicolumn{2}{|c|}{ Discontinued } & \multirow{2}{*}{ Odds Ratio } & \multirow{2}{*}{$p$ value } \\
\hline & & $\mathbf{n}^{*}$ & $\%$ & & \\
\hline Social class ${ }^{\S}$ & $\begin{array}{l}D / E \\
C \\
A / B\end{array}$ & $\begin{array}{l}18 \\
81 \\
11\end{array}$ & $\begin{array}{l}28.1 \\
32.5 \\
26.2\end{array}$ & $\begin{array}{l}1.00 \\
1.23 \\
0.91\end{array}$ & $\begin{array}{l}- \\
0.500 \\
0.827\end{array}$ \\
\hline Referral for follow-up after discharge & $\begin{array}{l}\text { No } \\
\text { Yes }\end{array}$ & $\begin{array}{c}5 \\
107\end{array}$ & $\begin{array}{l}71.4 \\
30.5\end{array}$ & $\begin{array}{l}1.00 \\
0.18\end{array}$ & 0.039 \\
\hline $\begin{array}{l}\text { Has the Benefício de Prestação Continuada (BPC) } \\
\text { [Continuous Provision Benefit] }\end{array}$ & $\begin{array}{l}\text { No } \\
\text { Yes }\end{array}$ & $\begin{array}{l}96 \\
10\end{array}$ & $\begin{array}{l}30.9 \\
32.3\end{array}$ & $\begin{array}{l}1.00 \\
1.07\end{array}$ & 0.873 \\
\hline Has another benefit for the child $\$$ & $\begin{array}{l}\text { No } \\
\text { Yes }\end{array}$ & $\begin{array}{l}94 \\
10\end{array}$ & $\begin{array}{l}30.3 \\
31.2\end{array}$ & $\begin{array}{l}1.00 \\
1.04\end{array}$ & 0.914 \\
\hline Difficulty to go to the outpatient service ${ }^{\S \dagger}$ & $\begin{array}{l}\text { No } \\
\text { Yes }\end{array}$ & $\begin{array}{l}58 \\
51\end{array}$ & $\begin{array}{l}27.4 \\
36.7\end{array}$ & $\begin{array}{l}1.00 \\
1.54\end{array}$ & 0.065 \\
\hline Own car ${ }^{\S}$ & $\begin{array}{l}\text { No } \\
\text { Yes }\end{array}$ & $\begin{array}{l}72 \\
37\end{array}$ & $\begin{array}{l}30.6 \\
31.9\end{array}$ & $\begin{array}{l}1.00 \\
1.06\end{array}$ & $\begin{array}{c}- \\
0.811\end{array}$ \\
\hline Bus $^{\S}$ & $\begin{array}{l}\text { No } \\
\text { Yes }\end{array}$ & $\begin{array}{l}62 \\
47\end{array}$ & $\begin{array}{l}29.8 \\
32.9\end{array}$ & $\begin{array}{l}1.00 \\
1.15\end{array}$ & 0.543 \\
\hline TFD (vehicle provided by the city hall) $)^{\S \ddagger}$ & $\begin{array}{l}\text { No } \\
\text { Yes }\end{array}$ & $\begin{array}{l}93 \\
16\end{array}$ & $\begin{array}{l}32.9 \\
23.5\end{array}$ & $\begin{array}{l}1.00 \\
0.63\end{array}$ & $0 . \overline{138}$ \\
\hline Distance $\$$ & $\begin{array}{l}<100 \mathrm{~km} \\
\geq 100 \mathrm{~km} \text { and }<200 \mathrm{~km} \\
\geq 200 \mathrm{~km}\end{array}$ & $\begin{array}{l}91 \\
15 \\
3\end{array}$ & $\begin{array}{l}31.9 \\
34.1 \\
18.8\end{array}$ & $\begin{array}{l}1.00 \\
1.10 \\
0.49\end{array}$ & $\begin{array}{l}- \\
0.775 \\
0.277\end{array}$ \\
\hline City & $\begin{array}{l}\text { Belo Horizonte } \\
\text { Other }\end{array}$ & $\begin{array}{l}40 \\
68\end{array}$ & $\begin{array}{l}32.5 \\
30.6\end{array}$ & $\begin{array}{l}1.00 \\
0.92\end{array}$ & $\begin{array}{c}- \\
0.717\end{array}$ \\
\hline Overall score - social support scale ${ }^{\S}$ & Mean (SD) & 106 & $85(1.6)$ & 1.16 & 0.844 \\
\hline
\end{tabular}

Note: * the value of $n$ changes according with the total number of records of the variable; $;$ Events observed at the time of hospital discharge; $\xi$ Events observed in the first outpatient appointment; $\neq$ Variable selected for the multivariate model.

Table 3 - Health needs-related factors and the discontinuity of outpatient follow-up of children who were hospitalized at the neonatal intensive care unit, Belo Horizonte, Minas Gerais, Brazil, 2016

\begin{tabular}{|c|c|c|c|c|c|}
\hline \multirow{2}{*}{ Variables } & & \multicolumn{2}{|c|}{ Discontinued } & \multirow{2}{*}{$\begin{array}{l}\text { Odds } \\
\text { Ratio }\end{array}$} & \multirow{2}{*}{$p$ value } \\
\hline & & $\mathbf{n}$ & $\%$ & & \\
\hline \multirow[t]{3}{*}{ Classification of the child's health } & Very good & 73 & 33.5 & 1.00 & - \\
\hline & Good & 34 & 27.4 & 0.75 & 0.245 \\
\hline & Average/Very poor & 1 & 11.1 & 0.25 & 0.193 \\
\hline \multirow[t]{3}{*}{ Chance of the baby having development problems due to the condition at birth } & High/Very high & 2 & 28.6 & 1.00 & - \\
\hline & Average & 12 & 27.3 & 0.94 & 0.943 \\
\hline & Low/Very low & 94 & 31.8 & 1.16 & 0.858 \\
\hline \multirow[t]{3}{*}{ Influence of your care for your child's development } & High/Very high & 101 & 30.9 & 1.00 & - \\
\hline & Average & 3 & 33.3 & 1.12 & 0.876 \\
\hline & Low/Very low & 4 & 28.6 & 0.90 & 0.854 \\
\hline \multirow{3}{*}{ Your child's need for outpatient care } & High/Very high & 86 & 34.5 & 1.00 & - \\
\hline & Average & 14 & 20.0 & 0.47 & 0.022 \\
\hline & Low/Very low & 9 & 29.0 & 0.78 & 0.542 \\
\hline
\end{tabular}

Note: $¥$ Variable selected for the multivariate model.

The data presented in Table 3 refer to the health needs-related factors and the discontinuity of outpatient follow-up of the children who were hospitalized at the NICU. These factors were evaluated by maternal appreciation concerning their children's health condition and need for outpatient follow-up. The "regular" understanding of mothers about their children's need for outpatient care was the variable that showed significant association with the discontinuity of follow-up $(p=0.022)$.

Table 4 presents the factors significantly associated with the children's discontinuance of the follow-up. In the multiple regression model, there was a significant influence of both variables on the discontinuance of the follow-up.
Table 4 - Final model with the variables that presented significant association with the discontinuity of outpatient follow-up of children who were hospitalized at the neonatal intensive care unit, Belo Horizonte, Minas Gerais, Brazil, 2016

\begin{tabular}{|c|c|c|c|c|c|}
\hline \multirow{2}{*}{ Variables } & & \multicolumn{2}{|c|}{ Discontinued } & \multirow{2}{*}{$\begin{array}{l}\text { Odds Ratio } \\
\text { (IC 95\%) }\end{array}$} & \multirow{2}{*}{$p$ value } \\
\hline & & $\mathbf{n}$ & $\%$ & & \\
\hline \multirow{2}{*}{$\begin{array}{l}\text { Mechanical } \\
\text { ventilation }\end{array}$} & No & 45 & 26.50 & 1.00 & \\
\hline & Yes & 56 & 38.10 & $1.68(1.04-2.72)$ & 0.035 \\
\hline \multirow{2}{*}{$\begin{array}{l}\text { Technology } \\
\text { dependence }\end{array}$} & No & 101 & 29.70 & 1.00 & \\
\hline & Yes & 11 & 61.10 & $3.54(1.32-9.5)$ & 0.012 \\
\hline
\end{tabular}




\section{DISCUSSION}

The results showed that a significant percentage of children who were hospitalized at the NICU referred to the follow-up has discontinued it $(31.28 \%, n=112)$ in the first year after hospital discharge, which corroborated other studies ${ }^{(7-8)}$. The experiences in the puerperium, combined with the demands of child care, are factors with potential consequences for depressive symptoms. The use of the Edinburgh scale showed that $23.91 \%$ of the interviewed mothers showed score $\geq 12$, indicating depressive symptomatology. This result is consistent with the values identified in the national literature in similar contexts ${ }^{(22-23)}$.

The average score of social support perceived by the participant mothers was of 85 , indicating that these mothers perceive the presence of a social support network, which contributes to the maternal capacity to deal with the feelings experienced ${ }^{(24)}$. The results found in this investigation are similar to the results of a longitudinal research conducted with pregnant women with fetuses with malformations, in which a general MOS mean of 88.4 (DP $=13.52$ ) stood out ${ }^{(25)}$.

International studies indicate that the greater the complexity of the children, the greater the families' adherence to follow-up programs ${ }^{(7-8)}$. Although the children who depended on technology require more complex care, in this study, the use of mechanical ventilation during hospitalization in the NICU and dependence on technology at the time of discharge were predisposing factors related to newborn's discontinuity of outpatient follow-up. A possible explanation for this result is that, in the face of their referral to other specialized services, aiming to meet their specific needs, the family could have chosen to carry out the follow-up care in the specialized service and discontinue the outpatient follow-up. However, we stress that the referral to specialized care or childcare in the basic care units should not exclude the continuity of the outpatient follow-up. These are appointments with different and complementary objectives, which together can promote a comprehensive approach to the children's needs $s^{(4)}$.

Assistance to children with continued care needs in the healthcare network is a challenge. There is a lack of knowledge regarding the quantity of children ${ }^{(26)}$, as well as regarding their specific care needs ${ }^{(27-28)}$. The assistance has been made by providing programmatic actions that do not include their specificities and there is a lack of strategies to identify them ${ }^{(28-29)}$. Additionally, on the national scene, it is possible to observe the incipience of public policies strategies and actions aimed at children with chronic conditions ${ }^{(26)}$, as well as the unpreparedness of basic care professionals to meet the specificities of needs of this group of children and difficulty of access to specialized services due to offer restriction ${ }^{(29-30)}$.

Considering that the use of health services suffer interference from the sociocultural and economic context in which the individuals are inserted ${ }^{(12)}$, the observed differences between this study and the international literature may also be explained by the distinct realities among the populations studied. In Brazil, the model of care is still prioritizing appointments aiming at intervention at the expense of preventive assistance ${ }^{(31)}$. With this choice, there is a production of actions directed to the restoration of the child's health that do not include the planning of care and the guidance necessary for its continuity ${ }^{(32)}$.
In this same perspective, the findings indicate that the socioeconomic characteristics of the population studied hinder this access, as they are families with limited availability of resources. Other factors identified that hinder the access to health services are the long distances, inadequate transport, and lack of clarification regarding the procedures needed to use the services. Studies have shown that these factors contribute to discontinuity of care and are the main reasons why these families prioritize greater complexity care, a choice that seeks the resolution of acute problems or problems recognized by them as priorities ${ }^{(7,29,32)}$.

The performance of professionals is another aspect that influences on continuity of care, especially at the time of discharge, when the children will go home. This is a transitional phase that requires support and professional guidance to the continuity of the child's care by the family ${ }^{(30,33)}$. The proper understanding of parents regarding their children's care needs results, largely, from a good communication between them and the health team concerning the evolution of the child and the possibilities for his/her future life. The outcomes of children considered at risk, of which are part those who were hospitalized at the NICU, are variable and can include death, survival with disabilities with different levels of complexity, and survival without any changes ${ }^{(34)}$. Although the parents' understanding of the needs of their children is essential, so that they can participate in the decisions regarding care, the great variability of outcomes makes the process of communication between parents and professionals challenging, and may compromise the decision about the use of health services. The extent of understanding of the perceived need is one of the factors for the use of the services ${ }^{(12)}$.

On this aspect, it is worth mentioning that this study showed that $20 \%$ of mothers considered as average their children's need for follow-up ( $p=0.022$ ). Despite this understanding, $62.11 \%$ of them assessed as their child's health condition as "good" ( $p=$ 0.245 ) and $85.3 \%$ of mothers considered as "low" or "very low" the chance their children having problems resulting from their condition at birth. This maternal evaluation may indicate an ignorance regarding the possibility of changes in the development of the child, as well as regarding the presence of less obvious changes in the initial phase of life, in which the child currently is. Similarly, in the Northeast region of Brazil, a study found that not all mothers of premature children could identify, without the aid of a professional, the changes in the development of their children ${ }^{(35)}$. In this context, the mothers may choose to give their children the same type of care they would give to a child with usual risk, reducing the opportunities for early identification of development compromises.

Recognition of illness or its possibility and how people react to it can define a faster search to the health service ${ }^{(12)}$. In this study, this recognition concerns maternal perception about the child's health need, considering it as responsible for their care decisions. The way the mother responds to these perceived needs may suffer interference from predisposing and enabling conditions, thus intensifying or reducing the use of health services.

The sample size of this study can be considered one of its strengths, especially when compared with national and international studies on the subject. 


\section{Study limitations}

The main limitation is that the study was carried out in a public philanthropic institution and most participants were from lower and middle class families, with complete elementary and high school. Also, during data collection, we observed the absence of systematic records regarding the referring of the children when they were no longer accompanied by the outpatient follow-up service, making it impossible to say if they were linked or not to another health service. These factors may limit the generalizability of the results.

\section{Contributions for the areas of nursing, health, or public policies}

The possibility to develop strategies that take into consideration predisposing, enabling, and health needs-related factors to reduce discontinuity of follow-up care stands out as the main contribution for the area of nursing. Understanding the risks of changes in the growth and development and the specificities of the needs of children who were hospitalized in neonatal units, by parents or caregivers, is essential to the continuity of care. Nursing and healthcare team professionals can contribute substantially to this, guiding them, during the planning of the NICU discharge, concerning the different and complementary objectives of the different appointments at the outpatient follow-up, specialized services, and in the puerperium basic care to meet the care needs of children at risk, especially those who used mechanical ventilation and were technology dependent. The latter are recognized as children at greater risk for discontinuing the outpatient follow-up, e.g., for being referred to specialized services. In addition, it is necessary to improve the integration between these services for the care network.

\section{CONCLUSIONS}

The use of mechanical ventilation at the NICU and technology dependence at the time of hospital discharge were associated with the discontinuation of outpatient follow-up of children at risk who were hospitalized at neonatal units. Knowledge of risk factors for non-attendance to outpatient follow-up, even before the discharge of the NICU, must be considered, seeking to build with the families strategies for continuity of care.

\section{REFERENCES}

1. Duarte ED, Silva KL, Tavares TS, Nishimot CLJ, Walty CMRF, Sena RR. Desafios do trabalho da enfermagem no cuidado às crianças com condições crônicas na atenção primária. Esc Anna Nery. 2015;19(4):648-55. doi: 10.5935/1414-8145.20150087

2. Blencowe H, Cousens S, Chou D, Oestergaard M, Say L, Moller AB, et al. Born too soon: the global epidemiology of 15 million preterm births. Reprod Health. 2013;10(Suppl 1):S2. doi: 10.1186/1742-4755-10-S1-S2

3. Liu L, Oza S, Hogan D, Chu Y, Perin J, Zhu J, et al. Global, regional, and national causes of child mortality in 2000-13, with projections to inform post-2015 priorities: an updated systematic analysis. Lancet. 2015;385(9966):430-40. doi: 10.1016/S0140-6736(16)32169-9

4. Ministério da Saúde (BR). Secretaria de Atenção à Saúde. Manual do Método Canguru: seguimento compartilhado entre a Atenção Hospitalar e a Atenção Básica. Brasília, DF: Ministério da Saúde; 2015.

5. Braga PP, Sena RR. Devir cuidadora de prematuro e os dispositivos constituintes da continuidade da atenção pós-alta. Texto Contexto Enferm. 2017;26(3):e3070016. doi: 10.1590/0104-07072017003070016

6. Synnes AR, Lefebvre F, Cake HA. Current status of neonatal follow-up in Canada. Paediatr Child Health. 2006;11(5):271-4.

7. Ballantyne M, Stevens B, Guttmann A, Willan AR, Rosenbaum P. Transition to neonatal follow-up programs: is attendance a problem? J Perinat Neonatal Nurs. 2012;26(1):90-8. doi: 10.1097/JPN.0b013e31823f900b

8. Fuller MG. Factors associated with high risk infant follow-up attendance [dissertation]. San Diego: University of San Diego; 2015.

9. Vázquez M, Iriondo M, Agut T, Poó MP, Ibáñez M, Krauel X. Abandonos en el seguimiento de recién nacidos de muy bajo peso antes de los 2 años. An Pediatr. 2011;74(5):309-16. doi: 10.1016/j.anpedi.2010.11.020

10. Aires LCP. Percepção dos profissionais de saúde da atenção básica sobre o seguimento do bebê pré-termo e/ou baixo peso e à sua família: interfaces com a terceira etapa do método canguru [dissertation]. Santa Catarina: Universidade Federal de Santa Catarina; 2015. doi: 10.1590/1983- 1447.2015.esp.56805

11. Freire LM, Camponêz PSP, Maciel IVL, Vieira CS, Bueno M, Duarte ED. Factors associated with non-adherence to outpatient follow-up of neonatal intensive care discharge. Rev Esc Enferm. 2018;52:e03372. doi: 10.1590/s1980-220x2017029703372

12. Andersen RM. Revisiting the behavioral model and access to medical care: does it matter? J Health Soc Behav. 1995;36(1):1-10.

13. Alfaia JRM, Rodrigues LR, Magalhães MM. Uso da escala de Edinburgh pelo enfermeiro na identificação da depressão pós parto: revisão integrativa da literatura. Rev Cienc Soc [Internet]. 2016[cited 2019 Jan 28];1(1). Available from: http://periodicos.estacio.br/index.php/ cienciaesociedade/article/viewArticle/2091

14. Trindade CRP, Hahn GV. Apoio social ao doente oncológico com base na escala do Medical Outcomes Study. Rev Enferm UFSM. 2016;6(1):112-22. doi: 10.5902/2179769218770

15. Magalhães FG, Goulart RMM, Prearo LC. Impacto de um programa de intervenção nutricional com idosos portadores de doença renal crônica. Cienc Saude Colet. 2018;23(8):2555-64. doi: 10.1590/1413-81232018238.23972016 
16. Santos IS, Matijasevich A, Tavares BF, Barros AJ, Botelho IP, Lapolli C, et al. Validation of the Edinburgh Postnatal Depression Scale (EPDS) in a sample of mothers from the 2004 Pelotas Birth Cohort Study. Cad Saude Publica. 2007;23(11):2577-88. doi: 10.1590/S0102-311X2007001100005

17. Griep RH, Chor D, Faerstein E, Werneck GL, Lopes CS. Validade de constructo de escala de apoio social do Medical Outcomes Study adaptada para o português no Estudo Pró-Saúde. Cad Saude Pública. 2005;21(3):703-14. doi: 10.1590/S0102-311X2005000300004

18. Instituto Brasileiro de Geografia e Estatística [Internet]. Síntese de indicadores sociais: uma análise das condições de vida da população brasileira 2015. n. 35. Rio de Janeiro; 2015[cited 2019 Jan 28]. Available from: https://biblioteca.ibge.gov.br/visualizacao/livros/liv95011.pdf

19. Brasil. Lei n॰ 8.742, de 9 de dezembro de 1993. Dispõe sobre a organização da Assistência Social e dá outras providências. Diário Oficial da União. 1993 Dec 9.

20. Hosmer DW, Lemeshow S. Applied logistic regression. 2nd. ed. New York: Wiley. 2000.

21. Nagelkerke NJD. A note on a general definition of the coefficient of determination. Biometrika. 1991;78(3):691-2. doi: 10.1093/biomet/78.3.691

22. Campos BC, Rodrigues OMPR. Depressão pós-parto materna: crenças, práticas de cuidado e estimulação de bebês no primeiro ano de vida. Psicol. 2015;46(4):483-92. doi: 10.15448/1980-8623.2015.4.20802

23. Marques LC, Silva WRV, Lima VP, Nunes JT, Ferreira AGN, Fernandes MNF. Saúde mental materna: rastreando os riscos causadores da depressão pós-parto. J Health NPEPS [Internet]. 2016[cited 2019 Jan 28];1(2):145-59. Available from: https://periodicos.unemat.br/index. php/jhnpeps/article/view/1588

24. Reid KM, Taylor MG. Social support, stress, and maternal postpartum depression: a comparison of supportive relationships. Soc Sci Res. 2015;54:246-62. doi: 10.1016/j.ssresearch.2015.08.009

25. Barros VC, Santos JFC, Lima LA, Fonseca DL, Lovisi GM. Depressão e apoio social em gestantes de fetos com malformações atendidas em um hospital materno-infantil público de referência no Rio de Janeiro. Cad Saude Colet. 2013;21(4):391-402. doi: 10.1590/ S1414-462X2013000400006

26. Tavares TS, Duarte ED, Sena RR. Direitos sociais das crianças com condições crônicas: análise crítica das políticas públicas brasileiras. Esc Anna Nery. 2017;21(4):e20160382. doi: 10.1590/2177-9465-EAN-2016-0382

27. Neves ET, Andres B, Silveira A, Arrué AM. A rede social de cuidados de uma criança com necessidade especial de saúde. Rev Eletronica Enferm. 2013;15(2):533-40. doi: 10.5216/ree.v15i2.17064

28. Duarte ED, Silva KL, Tavares TS, Nishimoto CLJ, Silva PM, Sena RR. Care of children with a chronic condition in primary care: challenges to the healthcare model. Texto Contexto Enferm. 2015;24(4):1009-17. doi: 10.1590/0104-0707201500003040014

29. Pedroso MLR, Motta MGC. Criança e família convivendo com a doença crônica: mesossistema em ligação com a vulnerabilidade programática. Texto Contexto Enferm [Internet]. 2013 [cited 2019 Apr 5];22(2):493-9. Available from: http://www.scielo.br/pdf/tce/v22n2/ en_v22n2a27.pdf

30. Tavares TS, Sena RR, Duarte ED. Implicações para o cuidado de enfermagem de egressos de unidade neonatal com condições crônicas. Rev RENE [Internet]. 2016[cited 2019 Apr 5];17(5):659-67. Available from: http://periodicos.ufc.br/rene/article/view/6197

31. Cabral IE, Moraes JRMM. Familiares cuidadores articulando rede social de criança com necessidades especiais de saúde. Rev Bras Enferm [Internet]. 2015 [cited 2019 Apr 5];68(6):1078-85. Available from: http://www.scielo.br/pdf/reben/v68n6/0034-7167-reben-68-06-1078.pdf

32. Nietsche EA, Nora AD, Lima MGR, Bottega JC, Neves ET, Sosmayer VL. Educação em saúde: planejamento e execução da alta em uma unidade de terapia intensiva neonatal. Esc Anna Nery. 2012;16(4):809-16. doi: 10.1590/S1414-81452012000400024

33. Nóbrega VM, Reichert APS, Vieira CS, Collet N. Longitudinalidade e continuidade do cuidado à criança e ao adolescente com doença crônica. Esc Anna Nery. 2015;19(4):656-63. doi: 10.5935/1414-8145.20150088.

34. Yee W, Ross S. Communicating with parents of high-risk infants in neonatal intensive care. Paediatr Child Health. 2006;11(5):291-4. doi: 10.1093/pch/11.5.291

35. Melo MRO, Andrade ISNS. Desenvolvimento infantil e prematuridade: uma reflexão sobre o conhecimento e as expectativas maternas. Rev Bras Promoc da Saude [Internet]. 2013 [cited 2019 Apr 5];26(4):548-53. Available from: http://www.redalyc.org/pdf/408/40831096013.pdf 